\title{
Pengaruh Kesiapan Belajar dan Motivasi Belajar Terhadap Hasil Belajar Mata Pelajaran Ekonomi pada Siswa Kelas X IPS SMA Negeri 1 Batang Angkola
}

\author{
Erlina Sari*1, Mariyatul KubtiyahRitonga² \\ Institut Pendidikan Tapanuli Selatan

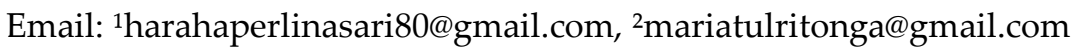

\begin{abstract}
This study aims to prove is there a significant influence between learning readiness and learning motivation simultaneously and partially on the learning outcomes of the student economics in class X SMA Negeri 1 Batang Angkola. The method used is descriptive method. Data collections technique using questionnaries and documentation. The data analysis technique used is simple and multiple linier regression test with the help of SPSS version 26.00. the results obtained prove that Fhitung is 9,479 with a value sig 0,001 while the $\mathrm{F}_{\text {tabel }}$ value at the $95 \%(\alpha=0,05)$ is 3,28 . Therefore, in both calculation, i.e $F$ hitung $>F$ tabel $(9,479>3,28)$ and value sig $(0,001<0,05)$ shows that there is a simultaneous and partial effect of learning readiness and learning motivation on the learning outcomes of economic subjects in class X IPS SMA N 1 Batang Angkola. This means that the better students learning readiness and the higher the motivation to learn, the higher the learning outcomes achieved. Learning readiness and learning motivation are learning principle that can affect student learning outcomes. With good learning readiness and followed by high learning motivation it will produce good learning outcomes. Motivation will form awareness and good learning readiness causing studens to learn actively.
\end{abstract}

Keyword: learning readiness, learning motivation, learning outcomes, economic subject

\section{Abstrak}

Penelitian ini bertujuan untuk membuktikan apakah ada pengaruh pengaruh yang signifikan antara kesiapan belajar dan motivasi belajar secara simultan dan parsial terhadap hasil belajar mata pelajaran ekonomi siswa pada kelas X IPS SMA Negeri 1 Batang Angkola. Metode penelitian yang digunakan adalah metode deskirptif. Teknik pengumpulan data menggunakan angket dan dokumentasi. Teknik analisis data yang digunakan adalah uji regresi linier sederhana dan berganda dengan bantuan SPSS versi 26.00. Hasil penelitian yang diperoleh membuktikan nilai Fhitung adalah 9,479 dengan nilai sig 0,001 sedangkan nilai $F_{\text {tabel }}$ pada tingkat kepercayaan $95 \%(\alpha=0,05)$ adalah 3.28 . Oleh karena itu pada kedua perhitungan yaitu $\mathrm{F}$ hitung $>\mathrm{F}$ tabel $(9,479>3,28)$ dan nilai sig $(0,001<0,05)$ 
menunjukkan bahwa terdapat pengaruh kesiapan belajar dan motivasi belajar secara simultan dan parsial terhadap hasil belajar mata pelajaran ekonomi pada siswa kelas X IPS SMA N 1 Batang Angkola. Artinya semakin baik kesiapan belajar siswa dan semakin tinggi motivasi belajar maka akan semakin tinggi pula hasil belajar yang diraih. Kesiapan belajar dan motivasi belajar siswa merupakan prinsip-prinsip belajar yang dapat mempengaruhi hasil belajar siswa. Dengan adanya kesiapan belajar yang baik dan diikuti motivasi belajar tinggi maka akan menghasilkan hasil belajar yang baik. Motivasi akan membentuk kesadaran dan kesiapan belajar yang baik menyebabkan siswa belajar secara aktif.

Kata Kunci: kesiapan belajar, motivasi belajar, hasil belajar, mata pelajaran ekonomi

\section{PENDAHULUAN}

Pendidikan adalah suatu usaha sadar yang terencana untuk memajukan kualitas anak bangsa dan juga untuk meningkatkan kualitas sumber daya manusianya itu sendiri. Pendidikan tidak terlepas dari perkembangan dan pertumbuhan ekonomi bangsa itu sendiri. Melalui sebuah pendidikan, sumber daya manusia yang semulanya kualitasnya rendah menjadi kualitas yang mampu bersaing dan mampu menghadapi perubahan pada lingkungan kerja yang nantinya ia akan bekerja. Untuk meningkatkan kualitas tersebut, pendidikan memperoleh tempat tertinggi dalam skala pembangunan pendidikan nasional, sehingga nanti pada akhirnya dapat menghasilkan lulusan yang memiliki intelektualitas yang tinggi dan memiliki kepribadian yang beriman dan bertakwa kepada Allah swt.

Menurut kacamata kebijakan pendidikan nasional, salah satu tujuan dari pemerataan kesempatan dalam pendidikan adalah untuk mengurangi dan meminimalisir kesenjangan sosial yang ada di tatanan lingkungan masyarakat agar masyarakat tersebut menjadi masyarakat yang modernisasi dan menuju masyarakat yang industrialisasi (Andriyani, 2020; Mulyaningsih, 2020). Salah satu cara untuk memecahkan persoalan tersebut adalah dengan cara meningkatkan kualitas sumber daya manusianya itu sendiri melalui lembaga pendidikan agar nantinya tercipta sumber daya manusia yang berkulitas. Ketika sumber daya manusianya berkulitas maka kita akan mampu mengelola berbagai sumber daya alam yang ada di negara ini.

Untuk mengelola sumber daya alam tersebut otomatis kita harus memiliki sumber daya manusia yang berkulitas yang ahli di bidangnya masing-masing, 
misalnya mulai dari perekonomian, pertanian, hukum, sosial dan sebagainya. Keahlian-keahlian tersebut diperoleh melalui jenjang pendidikan (Zaman et al., 2021).

Salah satu jenjang Pendidikan tersebut adalah jenjang pendidikan sekolah atas yang dikenal dengan jenjang Sekolah Menengah Atas (SMA). Di SMA banyak sekolah mata-mata pelajaran yang harus mampu dikuasai dan dituntaskan oleh siswa dan salah satunya adalah mata pelajaran ekonomi. Tujuan dari mata pelajaran ekonomi adalah agar siswa memiliki pengetahuan mengenai pertumbuhan dan perkembangan ekonomi baik di negaranya sendiri maupun perkembangan ekonomi dunia luar.

Banyak siswa yang beranggapan mata pelajaran ekonomi adalah mata pelajaran yang wajib dihafal atau mata pelajaran hafalan padahal kenyataannya adalah tidak (Nofiana, 2017; Kurniawati \& Zulfiati, 2018). Tetapi tujuan dari mata pelajaran ekonomi itu sendiri yang diharapkan sesuai dengan kurikulum 2013 adalah siswa mampu mengaitkan antara teori dengan kenyataan atau realitas kehidupan sehari-hari. Dengan tujuan tersebut diharapkan siswa mampu berfikir kritis agar ianya mampu mengatasi setiap persoalan dan masalah ekonomi yang dihadapi di kehidupan sehari-harinya. Ketika siswa mampu mengaitkannya maka hasil belajarnya pun akan meningkat.

Ketika seorang siswa belajar maka dalam diri siswa tersebut akan terjadi suatu proses perubahan misalnya adalah perubahan dalam hal tingkah laku. Dalam proses penilaian, perubahan dalam tingkah lalu tersebut dapat dilihat dari perubahan kognitif, perubahan afektif dan perubahan psikomotorik. Dalam proses pendidikan titik beratnya adalah terletak pada diri peserta didik yaitu akan terjadi proses belajar yang merupakan interaksi dengan pengalamanpengalamannya.

Menurut Sugandi (2007:63) mengemukakan hasil belajar merupakan uraian untuk menjawab pertanyaan" Apa yang harus digali, dipahami, dikerjakan siswa?" Hasil belajar ini merefleksikan keleluasaan, kedalaman, dan kompleksitas (secara bergradasi) dan digambarkan secara jelas serta dapat diukur dengan teknik-teknik penilaian tertentu.

Dari hasil pra survey pendahuluan, yang peneliti dapatkan dari guru mata pelajaran ekonomi bahwasanya dalam proses kegiatan belajar mengajar pada mata pelajaran ekonomi kelas X IPS SMA Negeri 1 Batang Angkola tidak menggunakan media LKS dan tidak semua siswa mempunyai buku pegangan 
ekonomi sebagai acuan untuk di pelajari di rumah ditambah dengan dengan kondisi pandemi saat ini menyebabkan siswa belajar sendiri dirumah melalui pembelajaran online atau daring. Yang menyebabkan siswa banyak yang malas belajar karena belajar sendiri dari rumah walaupun dikontrol guru melalui grup yang disediakan.

Berkaitan dengan keberhasilan kegiatan belajar mengajar, diketahui bahwa hasil belajar siswa kelas XI IPS SMA Negeri 1 Batang Angkola dalam materi pelajaran ekonomi masih berada di bawah KKM (Kriteria Ketuntasan Minimal) yaitu 70, dan hal tersebut menandakan bahwa mata pelajaran ekonomi masih sulit. Hal tersebut dapat dilihat dari nilai Nilai Ujian Akhir Sekolah (UAS) pada materi pelajaran ekonomi kelas X IPS pada semester ganjil tahun pelajaran 2020/2021 dapat dilihat pada tabel di bawah ini:

\section{Tabel 1}

\section{Nilai UAS Semester Ganjil Materi pelajaran Ekonomi di Kelas X IPS SMA} Negeri 1 Batang Angkola Tahun Pelajaran 2020/2021

\begin{tabular}{cccc}
\hline \hline No. & Kelas & Nilai & KKM \\
\hline \hline 1 & X IPS 1 & 70,75 & 70 \\
\hline 2 & X IPS 2 & 70,56 & 70 \\
\hline 3 & X IPS 3 & 69,69 & 70 \\
\hline 4 & X IPS 4 & 69,89 & 70 \\
\hline \hline
\end{tabular}

Sumber: Tata Usaha SMA Negeri 1 Batang Angkola

Tabel 1 di atas mengungkapkan bahwa nilai Ujian Akhir Sekolah (UAS) mata pelajaran Ekonomi Kelas X Semester Ganji di SMA Negeri 1 Batang Angkola Tahun Pelajaran 2020/2021 dari 4 kelas yang ada, nilai ujian tertinggi adalah Kelas X IPS 1 sebesar 70,75, sedangkan nilai ujian terendah ialah Kelas X IPS 3 dengan nilai sebesar 68,69 dengan Kriteria Ketuntasan Minimal (KKM) adalah 70 .

Kondisi semacam ini menimbulkan pemikiran dan keprihatinan, khususnya untuk hasil belajar siswa dalam materi pelajaran ekonomi. Banyak penyebab yang memungkinkan terjadinya hasil belajar menjadi rendah, hal ini dapat kita lihat berbagai macam faktor penyebabnya, diantaranya inteligensi, perhatian, minat, bakat, kesiapan, motivasi, pengulangan materi, faktor keluarga, faktor sekolah dan faktor masyarakat.

Ada beberapa faktor-faktor yang mempengaruhi hasil belajar, tetapi dapat digolongkan menjadi dua, yaitu: faktor internal yaitu faktor yang ada dalam diri 
individu yang sedang belajar. Faktor intern terdiri dari faktor jasmaniah (kesehatan dan cacat tubuh), faktor psikologis (inteligensi, perhatian, minat, bakat, motif, kematangan dan kesiapan), dan faktor kelelahan. Sedangkan faktor eksternal, yaitu faktor dari luar individu. Faktor ekstern terdiri dari: faktor keluarga, faktor sekolah dan faktor masyarakat. Dari teori di atas dapat disimpulkan bahwasannya kesiapan belajar dan motivasi belajar dapat mempengaruhi hasil belajar siswa (Slameto, 2003: 54-72)

Kesiapan adalah keadaan kapasitas yang ada pada diri siswa dalam hubungan dengan tujuan pengajaran tertentu (Hamalik, 2003:41). Faktor kesiapan, baik fisik maupun psikologis, merupakan kondisi awal suatu kegiatan belajar. dapat disimpulkan bahwasannya kesiapan belajar adalah kondisi awal suatu kegiatan belajar yang membuatnya siap untuk memberi respon/jawaban yang ada pada diri siswa dalam mencapai tujuan pengajaran tertentu (Darsono, 2000:27). Dengan adanya kesiapan belajar, siswa akan termotivasi untuk mengoptimalkan hasil belajarnya.

Motivasi belajar merupakan salah satu karakteristik yang dapat mempengaruhi aspek afektif. Siswa yang memiliki motivasi belajar akan memperhatikan dan berusaha untuk mengingat atas apa yang telah diajarkan oleh guru, karena semua itu untuk mencapai cita-citanya.

Fungsi motivasi belajar ada tiga yakni sebagai berikut: a) Mendorong manusia untuk berbuat Sebagai penggerak atau motor yang melepaskan energi. Motivasi dalam hal ini merupakan motor penggerak dari setiap kegiatan yang akan dikerjakan. b) Menentukan arah perbuatan yakni ke arah tujuan yang hendak dicapai. Dengan demikian motivasi dapat memberikan arah dan kegiatan yang harus dikerjakan sesuai dengan rumusan tujuannya. c) Menyeleksi perbuatan yakni menentukan perbuatan-perbuatan apa yang harus dikerjakan yang serasi guna mencapai tujuan, dengan menyisihkan perbuatan yang tidak bermanfaat dengan tujuan tersebut (Sardiman, 2001:83). Ketika siswa memiliki motivasi belajar yang tinggi ma tidak akan tertutup akan mempengaruhi hasil belajarnya dan nilainya juga akan tinggi karena siswa tersebut akan berusaha untuk mencoba mengerjakan soal-soal latihan terhadap materi pelajaran yang telah diberikan oleh guru. Menurut peneliti permasalahan kesiapan belajar dan motivasi belajar adalah satu factor yang memungkinkan terjadinya hasil belajar yang rendah. 


\section{METODE PENELITIAN}

Adapun jenis penelitian yang dilakukan adalah jenis jenis penelitian deskriptif kuantitatif karena penelitian ini bentuk deskripsinya adalah berbentuk angka atau statistic dan dijabarkan dalam bentuk angka-angka. Populasinya adalah seluruh siswa kelas X IPS di SMA Negeri 1 Batang Angkola. Teknik penarikan sampelnya adalah teknik random sampling dan yang terpilih adalah kelas X IPS 3. Instrumen penelitian digunakan untuk membantu mengumpulkan data yang dibutuhkan yaitu berdasarkan ketiga variabel tersebut. Teknik pengumpulan data menggunakan angket untuk variabel kesiapan belajar dan motivasi belajar dan hasil belajar mata pelajaran ekonomi diukur melalui nilai rata-rata raport di semester Ganjil pada Tahun Pelajaran 2020/2021. Teknik analisis data yang digunakan adalah uji regresi linier sederhana dan berganda dengan bantuan SPSS versi 26.00 .

\section{HASIL DAN PEMBAHASAN}

\section{Uji Asumsi Klasik}

Dari hasil uji penelitian yang telah dilakukan diperoleh nilai signifikasi uji KS > 0,05 yang berarti distribusi data dinyatakan normal. Berdasarkan hasil analisis dan uji normalitas bahwa nilai Asymp.Sig. (2-tailed) adalah 0.175 dan di atas nilai signifikan (0.05) dengan kata lain variabel residual berdistribusi normal. Dengan demikian dapat dikatakan bahwa hasil penelitian hasil belajar mata pelajaran ekonomi pada siswa kelas X IPS SMA Negeri 1 Batang Angkola berdistribusi normal.

Hasil uji linearitas diperoleh nilai signifikan Linearity sebesar 0.233 karena signifikansinya lebih dari 0,05 (0.233 > 0.05) maka dapat disimpulkan bahwa diantara variabel kesiapan belajar dan motivasi belajar dan pengulangan materi pelajaran dan hasil belajar mata pelajaran ekonomi terdapat hubungan yang linier. Untuk uji multikolinearitas diketahui bahwa nilai VIF mendekati 1 begitu juga dengan nilai tolerance jadi dapat disimpulkan bahwa tidak terdapat masalah multikolinearitas.

\section{Gambaran Kesiapan Belajar Terhadap Hasil Belajar Mata Pelajaran Ekonomi pada siswa Kelas X IPS SMA Negeri 1 Batang Angkola}

Berdasarkan hasil pengujian hipotesis diketahui bahwa ada pengaruh yang signifikan antara kesiapan belajar terhadap hasil belajar mata pelajaran ekonomi 
di Kelas X IPS SMA Negeri 1 Batang Angkola. Hasil penelitian diperoleh $t$ hitung $>t$ tabel $(2.674>2.039)$ dan nilai signifikansinya $0.003<0.05$. Artinya siswa yang memiliki kesiapan dan persiapan dalam belajarnya terutama kesiapan sebelum memulai belajar dan sebelum ujian diadakan maka nilai hasil belajarnya akan meningkat.

Adanya pengaruh yang signifikan antara kesiapan belajar terhadap hasil belajar mata pelajaran ekonomi sesuai dengan pendapat yang menyatakan bahwa kesiapan untuk belajar merupakan kondisi diri yang telah dipersiapkan untuk melakukan suatu kegiatan (Djamarah, 2002:35). Jika siswa memiliki persiapan dalam belajar maka hasil belajar mereka meningkat. Apabila siswa menginginkan hasil belajarnya meningkat otomatis siswa harus mempunyai persiapan dalam belajarnya. Ada beberapa faktor-faktor kesiapan belajar yang menurut peneliti yang bisa mempengaruhi kesiapan siswa itu sendiri untuk belajar misalnya kondisi fisik yang tidak memungkinkan siswa untuk tidak bisa belajar, misalnya sakit, yang pasti akan mempengaruhi faktor-faktor lain yang dibutuhkan untuk belajar dan juga kondisi psikologis yang tidak baik, misalnya risau, gelisah, tertekan, dan sebagainya yang merupakan kondisi awal yang tidak menguntungkan bagi kelancaran proses belajar siswa itu sendiri.

\section{Gambaran Motivasi Belajar Terhadap Hasil Belajar Mata Pelajaran Ekonomi Pada Siswa Kelas X IPS SMA Negeri 1 Batang Angkola}

Berdasarkan hasil pengujian hipotesis kedua diketahui bahwa ada pengaruh yang signifikan antara motivasi belajar terhadap hasil belajar mata pelajaran ekonomi pada siswa kelas X IPS SMA Negeri 1 Batang Angkola. Hasil penelitian ditemukan $\mathrm{t}$ hitung $>\mathrm{t}$ tabel $(4.374>2.039)$ dan nilai signifikansinya $0.000<0.05$. Artinya siswa yang memiliki motivasi yang tinggi dalam dirinya untuk belajar maka hasil belajarnya akan meningkat.

Adanya pengaruh pengaruh yang signifikan diantara kedua variabel (motivasi belajar dan hasil belajar mata pelajaran ekonomi) sesuai dengan teori yang mengemukakan bahwa dalam bahasa sehari-hari motivasi dinyatakan dengan maksud keinginan, hasrat, tekad, kebutuhan, kemauan, dorongan, kehendak, cita-cita, keharusan, kesediaan dan sebagainya (Nasution, 2004:77).

Menurut Darsono (2000:64-67) ada beberapa faktor yang mempengaruhi motivasi belajar adalah sebagai berikut: 1) Cita-cita atau aspirasi adalah suatu target yang ingin dicapai. 2) Dalam belajar dibutuhkan berbagai kemampuan 
misalnya pengamatan, perhatian, ingatan, daya pikir. 3) Kondisi siswa yang mempengaruhi motivasi belajar di sini berkaitan dengan kondisi fisik dan kondisi psikologis. 4) Kondisi lingkungan merupakan unsur-unsur yang datang dari luar diri siswa. 5) Unsur-unsur dinamis dalam belajar adalah unsur-unsur yang keberadaannya dalam proses belajar tidak stabil, kadang-kadang kuat, kadang-kadang lemah dan bahkan hilang sama sekali, khususnya kondisikondisi yang sifatnya kondisional, misalnya: gairah belajar. Artinya jika siswa memiliki motivasi untuk belajar maka hasil belajarnya akan meningkat.

\section{Gambaran Kesiapan Belajar dan Motivasi Belajar Terhadap Hasil Belajar Mata Pelajaran Ekonomi Pada Siswa Kelas X IPS SMA Negeri 1 Batang Angkola}

Berdasarkan hasil pengujian hipotesis diketahui bahwa ada pengaruh yang signifikan secara simultan dan parsial antara kesiapan belajar dan motivasi belajar terhadap hasil belajar mata pelajaran ekonomi di Kelas X IPS SMA Negeri 1 Batang Angkola. Hasil pengujian hipotesis tersebut dapat dilihat pada table 2 di bawah ini.

Tabel 2. ANOVAa

\begin{tabular}{llr|r|r|r|r}
\hline \hline \multicolumn{1}{l}{ Model } & Sum of Squares & \multicolumn{1}{c}{ Df } & Mean Square & \multicolumn{1}{c}{ F } & \multicolumn{1}{c}{ Sig. } \\
\hline \hline \multirow{2}{*}{1} & Regression & 196.715 & 2 & 98.357 & 9.479 & $.001^{\mathrm{b}}$ \\
\cline { 2 - 7 } & Residual & 321.667 & 31 & 10.376 & & \\
\cline { 2 - 7 } & Total & 518.382 & 33 & & & \\
\hline \hline
\end{tabular}

a. Dependent Variable: Hasil Belajar

b. Predictors: (Constant), Kesiapan Belajar, Motivasi Belajar

Hasil nilai tabel di atas adalah untuk menguji apakah terdapat pengaruh variabel independen (kesiapan belajar dan motivasi belajar) secara simultan terhadap hasil belajar siswa mata pelajaran ekonomi di kelas X IPS SMA N 1 Batang Angkola. Dari tabel 2 di atas mengungkapkan bahwa nilai Fhitung sebesar 9.479 dan $F$ tabel sebesar 3.28 (9.479 > 3.28) dengan nilai sig sebesar 0,001 membuktikan bahwa terdapat pengaruh kesiapan belajar dan motivasi belajar secara simultan terhadap hasil belajar mata pelajaran ekonomi pada siswa kelas X IPS SMA N 1 Batang Angkola.

Untuk menguji koefisien determinasinya dapat dilihat pada tabel 3 di bawah ini: 
Tabel 3. Model Summary

\begin{tabular}{ll|l|r|r} 
Model & R & R Square & Adjusted R Square & Std. Error of the Estimate \\
\hline 1 & $.616^{\mathrm{a}}$ & .379 & .339 & 3.22124 \\
\hline
\end{tabular}

a. Predictors: (Constant), Kesiapan Belajar, Motivasi Belajar

Dari tabel 3 di atas diperoleh nilai $R=0,616$ yang menunjukkan keberartian hubungan (relation) antara kedua variabel sebesar 61.6\% artinya hubungannya erat. Jadi ada hubungan erat sebesar $61.6 \%$ antara kesiapan belajar dan motivasi belajar terhadap hasil belajar mata pelajaran ekonomi pada siswa kelas X IPS SMA N 1 Batang Angkola. Hasil R Square diperoleh sebesar 0.379 dan nilai Adjusted R Square diperoleh sebesar 0,339 yang berarti sebesar 33.9\% hasil belajar siswa dapat dijelaskan oleh faktor kesiapan belajar dan motivasi belajar dan sisanya sebesar $66.1 \%$ diluar dari kedua faktor tersebut.

Untuk menguji apakah hipotesis yang diajukan diterima atau ditolak digunakan uji statistik yaitu uji $\mathrm{t}$ secara parsial. Jika $\mathrm{t}$ hitung $<\mathrm{t}$ tabel maka Ho diterima atau Ha ditolak sedangkan jika $t$ hitung $>t$ tabel maka Ho ditolak dan Ha diterima. Jika tingkat signifikasinya di bawah 0,05 maka Ho ditolak dan Ha diterima. Hasil yang telah diuji dapat dilihat pada tabel 4 di bawah ini:

\section{Tabel 4. Coefficients ${ }^{a}$}

\begin{tabular}{|c|c|c|c|c|c|c|}
\hline \multirow{2}{*}{\multicolumn{2}{|c|}{ Model }} & \multicolumn{2}{|c|}{$\begin{array}{l}\text { Unstandardized } \\
\text { Coefficients }\end{array}$} & \multirow{2}{*}{$\begin{array}{c}\text { Standardized } \\
\text { Coefficients } \\
\text { Beta } \\
\end{array}$} & \multirow[b]{2}{*}{$\mathrm{T}$} & \multirow[b]{2}{*}{ Sig. } \\
\hline & & $\mathrm{B}$ & Std. Error & & & \\
\hline \multirow[t]{3}{*}{1} & (Constant) & 79.900 & 30.318 & & 2.635 & .001 \\
\hline & Kesiapan Belajar & 11.375 & 6.795 & .238 & 2.674 & .003 \\
\hline & Motivasi Belajar & 22.924 & 5.247 & .613 & 4.374 & .000 \\
\hline
\end{tabular}

a. Dependent Variable: Hasil Belajar

Berdasarkan tabel 4 di atas $t$ hitung diperoleh $2.635>t$ tabel 2.039 artinya $2.674>$ 2.039 dan besarnya nilai signifikansi variabel bebas (kesiapan belajar dan motivasi belajar) pada uji $\mathrm{t}$ adalah 0.001 atau $<0.05$. Hal ini menunjukkan bahwa Ho ditolak dan $\mathrm{H} 1$ diterima sehingga variabel bebas kesiapan belajar dan motivasi belajar berpengaruh secara signifikan secara parsial terhadap hasil belajar siswa pada mata pelajaran ekonomi sehingga Ha diterima.

Berdasarkan hasil output tabel 4 di atas tersebut diperoleh rumus persamaan regresinya:

$$
\mathrm{Y}=79.900+11.375 \mathrm{x}_{1}+22.924 \mathrm{x}_{2}
$$

Nilai sig diperoleh sebesar $(0,003)$ di bawah (lebih kecil dari) 0,05 dan nilai $t$ hitung $(2,672)>t$ tabel $(2.039)$ artinya jika ditingkatkan nilai variabel kesiapan belajar 
sebesar satu satuan (unit) maka hasil belajar pada mata pelajaran ekonomi pada siswa kelas X IPS SMA N 1 Batang Angkola (Y) akan meningkat sebesar 11.375 satuan (unit). Jadi dapat disimpulkan variabel kesiapan belajar (X1) secara positif dan signifikan terhadap hasil belajar mata pelajaran ekonomi pada siswa kelas $X$ IPS SMA N 1 Batang Angkola.

Nilai sig diperoleh sebesar $(0,000)$ di bawah (lebih kecil dari) 0,05 dan nilai t hitung $(4.374)<\mathrm{t}$ tabel (2.039) artinya jika ditingkatkan variabel motivasi belajar sebesar satu satuan (unit) maka hasil belajar mata pelajaran ekonomi pada siswa kelas X IPS SMA N 1 Batang Angkola (Y) akan meningkat sebesar 22.924 satuan (unit). Jadi dapat disimpulkan variabel motivasi belajar (X2) secara positif dan signikan terhadap hasil belajar mata pelajaran ekonomi pada siswa kelas $X$ IPS SMA N 1 Batang Angkola.

Adanya pengaruh pengaruh yang signifikan secara simultan dan parsial antara kesiapan belajar dan motivasi belajar terhadap hasil belajar mata pelajaran ekonomi sejalan dengan pendapat dari Slameto (2003: 54-72) yang mengungkapkan bahwa faktor-faktor yang mempengaruhi hasil belajar banyak jenisnya, tetapi dapat digolongkan menjadi dua, yaitu faktor internal dan faktor eksternal. Faktor internal yaitu faktor yang ada dalam diri individu yang sedang belajar, yang terdiri dari: (a) faktor jasmaniah (kesehatan dan cacat tubuh); (b) faktor psikologis (inteligensi, perhatian, minat, bakat, motif, kematangan dan kesiapan); dan (c) faktor kelelahan. Faktor eksternal, yaitu faktor dari luar individu yang terdiri dari: (a) faktor keluarga, (b) faktor sekolah, dan (c) faktor masyarakat.

Kesiapan belajar dan motivasi belajar siswa merupakan prinsip-prinsip belajar yang dapat mempengaruhi hasil belajar siswa. Dengan adanya kesiapan belajar yang baik dan diikuti motivasi belajar tinggi maka akan menghasilkan hasil belajar yang baik. Motivasi akan membentuk kesadaran dan kesiapan belajar yang baik menyebabkan siswa belajar secara aktif. Dari uraian di atas diketahui bahwa semakin baik kesiapan belajar siswa dan semakin tinggi motivasi belajar maka akan semakin tinggi pula hasil belajar yang diraih. Maka dapat disimpulkan bahwa ada pengaruh yang signifikan secara simultan dan parsial antara motivasi belajar dan kesiapan belajar siswa terhadap hasil belajar mata pelajaran ekonomi pada siswa kelas X IPS SMA Negeri 1 Batang Angkola. 


\section{KESIMPULAN}

Dari hasil penelitian dapat disimpulkan bahwasannya terdapat pengaruh yang signifikan baik secara simultan dan parsial antara kesiapan belajar dan motivasi belajar terhadap hasil belajar mata pelajaran ekonomi di Kelas X IPS SMA Negeri 1 Batang Angkola dapat dilihat dari nilai Fhitung diperoleh sebesar 9.479 dengan nilai sig 0,001. Sedangkan $\mathrm{F}_{\text {tabel }}$ pada tingkat kepercayaan 95\% ( $\alpha=$ $0,05)$ adalah 3.28. Oleh karena itu pada kedua perhitungan yaitu $\mathrm{F}$ hitung $>\mathrm{F}$ tabel $(9.479>3.28)$ dan nilai sig $(0,001<0,05)$ membuktikan bahwa terdapat pengaruh variabel kesiapan belajar dan motivasi belajar secara simultan terhadap hasil belajar mata pelajaran ekonomi pada siswa kelas X IPS SMA N 1 Batang Angkola. Kemudian hasil uji $\mathrm{t}$ secara parsial diperoleh $2.635>\mathrm{t}$ tabel 2.039 artinya $2.635>2.039$ dan besarnya nilai signifikansi variabel bebas (kesiapan belajar dan motivasi belajar) pada uji $\mathrm{t}$ adalah 0.001 atau $<0.05$. Hal ini menunjukkan bahwa Ho ditolak dan H1 diterima sehingga variabel bebas kesiapan belajar dan motivasi belajar berpengaruh secara signifikan secara parsial terhadap hasil belajar siswa pada mata pelajaran ekonomi sehingga $\mathrm{Ha}$ diterima.

Kesiapan belajar dan motivasi belajar siswa merupakan prinsip-prinsip belajar yang dapat mempengaruhi hasil belajar siswa. Dengan adanya kesiapan belajar yang baik dan diikuti motivasi belajar tinggi maka akan menghasilkan hasil belajar yang baik. Motivasi akan membentuk kesadaran dan kesiapan belajar yang baik menyebabkan siswa belajar secara aktif. Jadi semakin baik kesiapan belajar siswa dan semakin tinggi motivasi belajar maka akan semakin tinggi pula hasil belajar yang diraih. 


\section{DAFTAR PUSTAKA}

Akdon. (2010). Aplikasi Statistika dan Metode Penelitian Untuk Administrasi Pendidikan. Bandung: Dewa Ruci

Algifari, (2000). Analisis Regresi Teori Kasus dan Solusi. Yogyakarta: PT BPEE

Ali, Mohammad. (1993). Penelitian Kependidikan, Prosedur dan Strategi. Bandung: Angkasa

Andriyani, J. (2020). Peran Lingkungan Keluarga Dalam Mengatasi Kenakalan Remaja. At-Taujih: Bimbingan Dan Konseling Islam, 3(1), 86-98. https://doi.org/10.22373/taujih.v3i1.7235

Anni, Chatarina Tri. (2004). Psikologi Belajar. Semarang: UPT UNNES Press

Arikunto, Suharsimi. (2019). Prosedur Penelitian Suatu Pendekatan Praktik. Jakarta: Rineka Cipta

Budiningsih, Asri. (2012). Belajar dan Pembelajaran. Jakarta: Rineka Cipta

Darsono. (2000). Belajar dan Pembelajaran. Semarang: IKIP Semarang Press

Dimyati dan Mudjiono. (2006). Belajar dan Pembelajaran. Jakarta: Depdikbud Dirjen Pendidikan Dasar dan Menengah Direktorat Pendidikan Menengah Umum

Djamarah, Syaiful Bahri. (2002). Rahasia Sukses Belajar. Jakarta: Rineka Cipta

Ghozali, Imam. (2005). Analisis Multivariate degan Program SPSS. Semarang: Badan Penerbit UNDIP

Hadi, Sutrisno. (2000). Analisis Regresi. Yogyakarta: Andi Offset

Hamalik, Oemar. (2003). Perencanaan Pengajaran Berdasarkan Pendekatan Sistem. Jakarta: Bumi Aksara

Iskandar Putong. (2010). Economi Pengantar Mikro dan Makro. Jakarta: Mitra Wacana Media

Kurniawati, K., \& Zulfiati, Z. (2018). Evaluasi Program Pembelajaran Sejarah Terintegrasi dalam Mata Pelajaran IPS di SMPN 4 Kota Bekasi. Jurnal Pendidikan Sejarah, 7(1), 1-28. https://doi.org/10.21009/JPS.071.01

Misbahuddin dan Ikbal Hasan. (2013). Analisis Data Penelitian Dengan Statistik. Jakarta: Bumi Aksara 
Mulyaningsih, M. (2020). Transformasi Kearifan Lokal Sebagai Modal Sosial Dalam Mengatasi Persoalan Kehidupan Masyarakat Daerah Perbatasan Pada Menghadapi Asia Future Shock Tahun 2020 (Hasil Kolaborasi Penelitian Daerah Komplek Dan Perkotaan). Jurnal Sekretaris dan Administrasi Bisnis, 4(2), 105-115. https://doi.org/10.31104/jsab.v4i2.150

Nasution, S. (2004). Didaktik Asas-Asas Mengajar. Jakarta: Bumi Aksara

Nofiana, M. (2017). Profil Kemampuan Literasi Sains Siswa SMP di Kota Purwokerto Ditinjau dari Aspek Konten, Proses, dan Konteks Sains. JSSH (Jurnal Sains Sosial Dan Humaniora), 1(2), 77-84. https://doi.org/10.30595/jssh.v1i2.1682

Poerwadarminto. (2011). Kamus Besar Bahasa Indonesia. Jakarta: Depdikbud

Purwanto, Ngalim. (2008). Psikologi Pendidikan. Bandung: PT. Remaja Rosdakarya

Riyanto, Yatim. (2014). Paradigma Baru Pembelajaran. Sebagai Referensi bagi Pendidik dalam Implementasi Pembelajaran yang Efektif dan Berkualitas. Kencana: Kharisma Putra Utama

Sardiman, AM. (2001). Interaksi dan Motivasi dalam Belajar Mengajar. Jakarta: Raja Grafindo Persada

Slameto. (2003). Belajar dan Faktor-faktor yang Mempengaruhinya. Jakarta: PT. Rineka Cipta.

Soemanto, Wasty. (2003). Psikologi Pendidikan. Jakarta: Rineka Cipta

Sudjana, Nana. (2011). Dasar-Dasar Proses Belajar Mengajar, Bandung: Sinar Baru Algensindo

Sugandi, Ahmad. (2007). Teori Pembelajaran.Semarang: UPT MKK. Universitas Negeri Semarang

Sugiyono. (2002). Statistik untuk Penelitian. Bandung: Alfabeta Soemanto (2008). Metode Penelitian Administrasi. Bandung: CV. Alfabeta

Sukardi. (2008). Metode Penelitian Pendidikan Kompetensi dan Praktiknya. Jakarta: PT. Bumi Aksara

Sukmadinata, Nana Syaodih. (2017). Metode Penelitian Pendidikan. Bandung: PT Remaja Rosdakarya

Sulistyo. (2010). Teori Ekonomi Makro. Jakarta: Universitas Terbuka 
Syafrizal Helmi Situmorang, Doli M. Ja'far Dalimunthe, Iskandar Muda, Muslich Lutfi, Syahyunan. (2008). Analisis Data Penelitian (Menggunakan Program SPSS. USU Press

Syah, Muhibbin. (2004). Psikologi Pendidikan dengan Pendidikana Guru. Bandung: PT Remaja Rosdakarya

Thabrani, Hasbullah. (1994). Rahasia Sukses Belajar. Jakarta: PT Raja Grafindo Persada

Thursan, Hakim (2008). Belajar Secara Efektif, Jakarta: Puspa Swara

Wasty. (1998). Psikologi Pendidikan. Jakarta: Rineka Cipta

Zaman, N., Syafrizal, S., Chaerul, M., Purba, S., Bachtiar, E., Simarmata, H. M. P., Basmar, E., Sudarmanto, E., Koesriwulandari, K., \& Hastuti, P. (2021). Sumber Daya dan Kesejahteraan Masyarakat. Yayasan Kita Menulis. https://books.google.co.id/books?hl=en\&lr=\&id=bKIjEAAAQBAJ 